Hydrology and Earth System Sciences, 5(3), 283-297 (2001) C C EGS

\title{
Recovery from acidification in European surface waters
}

\author{
C.D. Evans ${ }^{1}$, J.M. Cullen ${ }^{1}$, C. Alewell ${ }^{2}$, J. Kopácek ${ }^{3}$, A. Marchetto ${ }^{4}$, F. Moldan ${ }^{5}$, A. Prechtel ${ }^{2}$, \\ M. Rogora ${ }^{3}$, J. Veselý ${ }^{6}$ and R. Wright ${ }^{7}$. \\ ${ }^{1}$ Centre for Ecology and Hydrology, Wallingford, Oxon OX10 8BB, UK \\ ${ }^{2}$ Institute for Terrestrial Ecosystem Research (BITÖK), University of Bayreuth, D-95440 Bayreuth,Germany \\ ${ }^{3}$ Hydrobiological Institute AS CR, Na sádkách 7, 37005 Èeské Budejovice, Czech Republic \\ ${ }^{4}$ Consiglio Nazionale delle Richerche - Istituto Italiano di Idrobiologia, 28922 Verbania Pallanza, Italy \\ ${ }^{5}$ Swedish Environmental Research Institute (IVL), Dagjämningsgatan 1, Box 47086, S-402 58 Göteborg, Sweden \\ ${ }^{6}$ Czech Geological Survey, Geologická 6, 15200 Praha 5, Czech Republic \\ ${ }^{7}$ Norwegian Institute for Water Research (NIVA), Box 173, Kjelsas, N-0411 Oslo, Norway \\ Email for corresponding author: cev@ceh.ac.uk
}

\begin{abstract}
Water quality data for 56 long-term monitoring sites in eight European countries are used to assess freshwater responses to reductions in acid deposition at a large spatial scale. In a consistent analysis of trends from 1980 onwards, the majority of surface waters (38 of 56) showed significant $(\mathrm{p} \leq 0.05)$ decreasing trends in pollution-derived sulphate. Only two sites showed a significant increase. Nitrate, on the other hand, had a much weaker and more varied pattern, with no significant trend at 35 of 56 sites, decreases at some sites in Scandinavia and Central Europe, and increases at some sites in Italy and the UK. The general reduction in surface water acid anion concentrations has led to increases in acid neutralising capacity (significant at 27 of 56 sites) but has also been offset in part by decreases in base cations, particularly calcium (significant at 26 of 56 sites), indicating that much of the improvement in runoff quality to date has been the result of decreasing ionic strength. Increases in acid neutralising capacity have been accompanied by increases in $\mathrm{pH}$ and decreases in aluminium, although fewer trends were significant ( $\mathrm{pH} 19$ of 56, aluminium 13 of 53). Increases in $\mathrm{pH}$ appear to have been limited in some areas by rising concentrations of organic acids. Within a general trend towards recovery, some inter-regional variation is evident, with recovery strongest in the Czech Republic and Slovakia, moderate in Scandinavia and the United Kingdom, and apparently weakest in Germany.
\end{abstract}

Keywords: acidification, recovery, European trends, sulphate, nitrate, acid neutralising capacity

\section{Introduction}

The emission, and subsequent deposition, of acidifying sulphur ( $\mathrm{S}$ ) and nitrogen $(\mathrm{N})$ compounds has resulted in the acidification of surface waters in many geologically sensitive regions of Europe (Rodhe et al., 1995). As a transboundary pollution issue, legislation to reduce acidifying emissions has taken place at an international level, through the Convention on Long-Range Transboundary Air Pollution of the United Nations Economic Commission for Europe (UN-ECE). The first agreement to restrict $\mathrm{S}$ emissions was reached in 1985 and called for a 30\% cut relative to 1980 in all countries. Subsequent agreements have resulted in further emissions reductions for $\mathrm{S}$, the introduction of emissions controls for $\mathrm{N}$, and in a more targeted strategy aimed at reducing critical load exceedance for terrestrial and freshwater ecosystems at the European scale. The most recent multi-pollutant, multi-effect (Gothenburg) protocol, signed in 1999, incorporates additional air pollutants and is intended to bring a 63\% reduction in European S emissions relative to 1990 (approximately $80 \%$ relative to 1980), and a $41 \%$ reduction in oxidised $\mathrm{N}$ emissions relative to 1990 (UN-ECE, 1999). Current $\mathrm{S}$ emissions are less than half the 1980 levels, while oxidised $\mathrm{N}$ emissions have declined by about 20\% (Verstreng and Støren, 2000).

Given these major reductions in emissions of the dominant acidifying pollutant over the last two decades, substantial improvements should have occurred in the affected ecosystems over the same period. Analysis of long-term trends in freshwater data provides an important means to assess whether this expected improvement has in fact 
occurred and, if so, to what extent this represents a return to 'good ecological status' as mandated by the European Union Water Framework Directive (EU, 2000). Long-term data also aid understanding of the acidification process and contribute to the development of critical loads, dynamic models and prediction of the benefits of current and future emissions control agreements.

Long-term water quality trends have previously been examined for many different sites (e.g. Christophersen et al., 1990; Reynolds et al., 1997), regions (e.g. Harriman et al., 1995; Soulsby et al., 1997; Veselý et al., 1998; Kopácek et al., 1998; Mosello et al., 2000) and countries (e.g. Mannio and Vuorenmaa, 1995; Skjelkvåle et al. 1998; Wilander and Lundin, 1999; Monteith and Evans, 2000). The co-ordinated international strategy on emission controls suggests that trends should be qualitatively similar from country to country; therefore, combining trend data for different countries should provide valuable additional information regarding the spatial extent, consistency and magnitude of recovery at the European scale. To date, studies of longterm trends in European surface waters have been undertaken within the framework of the International Cooperative Programme on Assessment and Monitoring of Acidification of Rivers and Lakes (ICP-Waters), which compiles data from monitoring programmes throughout much of Europe and North America. Stoddard et al. (1999) analysed trends for 1980-1989 (41 sites) and 1990-1995 (74 sites) for the ICP-Waters network with additional data for the UK from the Acid Waters Monitoring Network. Sites were divided into three regions (Nordic Countries, United Kingdom, North/Central Europe). Skjelkvåle et al. (2000) updated this with an assessment of trends between 1989 and 1998 for 64 European surface waters. The regions selected for this analysis (Northern Nordic Countries, Southern Nordic Countries and UK, and Central Europe) differed from those selected by Stoddard et al. (1999). Both studies provided evidence for recovery from acidification at many sites but trends varied considerably between regions. In particular, few recovery trends were observed in the UK and in continental Europe, although large sulphate $\left(\mathrm{SO}_{4}\right)$ reductions were recorded, Skjelkvåle et al. (2000) found significant heterogeneity in acidity trends.

The current study builds on the results of previous work by examining trends at 56 sites included in the RECOVER:2010 project. Most of these sites are not part of ICP-Waters and they, therefore, provide a validation of previous observations, as well as incorporating more recent data. Site trends are considered individually, but an attempt is made to identify general patterns of chemical change at the European scale and the extent to which systematic differences arise between trends in a total of six regions (primarily individual countries). The European-scale assessment presented here is also supported by more detailed analyses of trends in each individual region by Alewell et al. (2001), Rogora et al. (2001), Moldan et al. (2001), Skjelkvåle et al. (2001), Evans and Monteith (2001) and Kopácek et al. (2001).

\section{Site description and methodology}

The analysis of trends for RECOVER:2010 draws together data for a total of 56 lakes and streams from eight European countries (Fig. 1). These sites cover a wide range of acidsensitive landscapes, from high-altitude alpine meadows in the Italian Alps and Tatra Mountains of Slovakia through Central European and Scandinavian forests to peaty moorlands in the UK (Table 1). A full list of the sites used is given in Appendix 1 and more detailed site descriptions are provided elsewhere in this volume.

Since these data have been collated from a large number of different monitoring programmes, there is inevitably some heterogeneity in dataset characteristics, with start dates ranging from 1971 to 1988, sampling frequencies from weekly to monthly at streams, and monthly to yearly at lakes, and varying sets of measured determinands. Here, a set of six key variables are considered: acid neutralising capacity (ANC), $\mathrm{pH}$, non-marine sulphate $\left(\mathrm{xSO}_{4}\right)$, calcium $(\mathrm{Ca})$, nitrate $\left(\mathrm{NO}_{3}\right)$, and soluble aluminium $(\mathrm{Al})$. These variables were measured at all study sites with the exception of $\mathrm{Al}$, for which data were unavailable for three of the five Italian sites. ANC was calculated as the difference in the equivalent sum of base cations $(\mathrm{Ca}$, magnesium $(\mathrm{Mg})$, sodium $(\mathrm{Na})$, potassium $(\mathrm{K})$ ) and acid anions (chloride $(\mathrm{Cl}), \mathrm{SO}_{4}, \mathrm{NO}_{3}$ ) in all regions except the UK, where it was calculated by adjusting measured alkalinity for inorganic aluminium and organic acids (Evans and Monteith, 2001). This alternative estimate is theoretically equivalent to ANC calculated from the difference between the sum of base cations and the sum of acid anions. It is used for sites in the UK, which have high sea-salt concentrations, because it is less influenced by measurement errors at high ionic strengths (Evans et al., 2001). Non-marine $\mathrm{SO}_{4}$ was calculated by subtracting the marine $\mathrm{SO}_{4}$, calculated based on the sea-water $\mathrm{SO}_{4} / \mathrm{Cl}$ ratio, from total $\mathrm{SO}_{4}$. In central Europe, where marine inputs are minor, $\mathrm{xSO}_{4}$ is approximately equal to $\mathrm{SO}_{4}$, but in coastal areas of the UK and Scandinavia, it is necessary to consider $\mathrm{xSO}_{4}$ in order to distinguish changes in anthropogenic $\mathrm{SO}_{4}$ from climate-related variations in sea-salt deposition.

The six variables selected illustrate the main surface water responses to changes in acid deposition, with $\mathrm{xSO}_{4}$ and $\mathrm{NO}_{3}$ representing the major acidifying anions, and $\mathrm{ANC}, \mathrm{pH}$ and $\mathrm{Al}$ providing measures of surface water acidity and toxicity. 


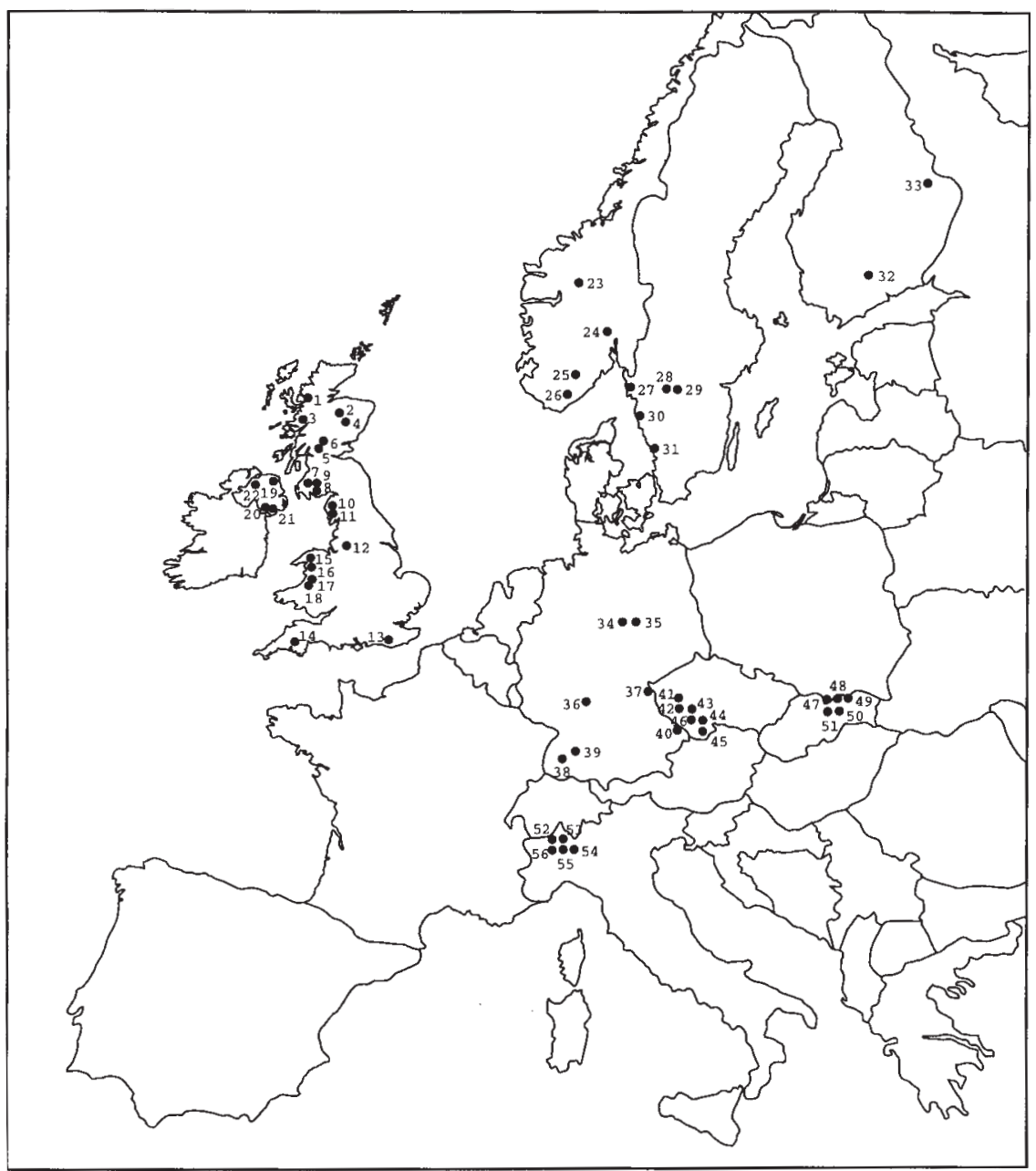

Fig. 1. Sites used in European trend assessment. Site numbers correspond to those in Appendix 1

Table 1. General characteristics of monitoring sites in each country

\begin{tabular}{|c|c|c|c|c|c|c|c|}
\hline Country & $\begin{array}{l}\text { Number of } \\
\text { lakes }\end{array}$ & $\begin{array}{l}\text { Number of } \\
\text { streams }\end{array}$ & Altitude range & Land-cover & Soils & Geology & $\begin{array}{l}\text { ANC range } \\
(\mu e q l-1)\end{array}$ \\
\hline Italy & 2 & 3 & 193 to 2269 & $\begin{array}{l}\text { Rock/alpine meadow (lakes) } \\
\text { Mixed forest (streams) }\end{array}$ & Rankers & $\begin{array}{l}\text { Granite, gneiss, } \\
\text { micaschist }\end{array}$ & 4 to 216 \\
\hline Slovakia & 5 & - & 1477 to 2145 & $\begin{array}{l}\text { Rock/alpine meadow (3) } \\
\text { coniferous forest ( } 2 \text { ) }\end{array}$ & Thin podzolic & Granite & -11 to 280 \\
\hline $\begin{array}{l}\text { Czech } \\
\text { Republic }\end{array}$ & 6 & - & 1008 to 1096 & Spruce forest & Podzols & $\begin{array}{l}\text { Schist, gneiss, } \\
\text { granite }\end{array}$ & -38 to 7 \\
\hline Germany* & - & 7 & 385 to 1355 & $\begin{array}{l}\text { Spruce forest (6) } \\
\text { Beech forest (1) }\end{array}$ & $\begin{array}{l}\text { Cambisols, } \\
\text { podzols }\end{array}$ & $\begin{array}{l}\text { Granite, gneiss, } \\
\text { sandstone }\end{array}$ & -140 to \\
\hline Finland & - & 2 & 150 to 165 & Spruce, pine, birch, aspen & $\begin{array}{l}\text { Podzols, peats, } \\
\text { cambisols }\end{array}$ & $\begin{array}{l}\text { Gneiss, } \\
\text { granodiorite }\end{array}$ & 71 to 105 \\
\hline Sweden & - & 5 & 75 to 245 & $\begin{array}{l}\text { Spruce, pine, birch, } \\
\text { aspen, heather }\end{array}$ & Podzols & $\begin{array}{l}\text { Gneiss, granite, } \\
\text { moraine }\end{array}$ & \\
\hline Norway & - & 4 & 200 to 580 & $\begin{array}{l}\text { Spruce, pine, birch, } \\
\text { heather }\end{array}$ & $\begin{array}{l}\text { Podzols, } \\
\text { peaty rankers }\end{array}$ & Granite, gneiss & -38 to 2 \\
\hline $\begin{array}{l}\text { United } \\
\text { Kingdom }\end{array}$ & 11 & 11 & 10 to 785 & $\begin{array}{l}\text { Grass/heather moorland (17) } \\
\text { Coniferous forest (5) }\end{array}$ & $\begin{array}{l}\text { Peat, podzol, } \\
\text { gley, ranker }\end{array}$ & $\begin{array}{l}\text { Granite, schist, } \\
\text { sedimentary. }\end{array}$ & -32 to 168 \\
\hline
\end{tabular}


Calcium represents the major source of base cation buffering at most sites and unlike the other main base cations, $\mathrm{Na}$ and $\mathrm{Mg}$, is not strongly affected by a large marine component. Chloride, which is primarily marine-derived, exhibits few long-term trends and was not therefore considered here. Other variables of interest, such as Dissolved Organic Carbon (DOC), alkalinity, and the inorganic (toxic) and organic (non-toxic) components of Al, could not be incorporated into the European-scale analysis as they were not measured at a sufficient number of sites. Additional variables are, however, considered where data are available in the accompanying regional studies.

For data series with limited data (e.g. annual), the MannKendall Test (MKT) was applied (Mann, 1945; Kendall, 1975). MKT is a non-parametric method of trend analysis which is robust with regard to non-normality, missing or censored data. All data pairs within a time series $\left(x_{j}, x_{k}\right.$, where $\mathrm{j}>\mathrm{k})$ are assigned a function $\operatorname{sgn}\left(\mathrm{x}_{\mathrm{j}}-\mathrm{x}_{\mathrm{k}}\right)$ with values of $+1,0$ or -1 depending on the sign of $x_{j}-x_{k}$. These are then summed to give the Mann-Kendall statistic S (Eqn. 1):

$$
S=\sum_{k=1}^{n-1} \sum_{j=k+1}^{n} \operatorname{sgn}\left(x_{j}-x_{k}\right)
$$

where $n$ is the number of data values. The value of $S$, together with calculated variance, $\operatorname{Var}(\mathrm{S})$, are used to derive a test statistic Z, which is positive if the trend is upward and negative if the trend is downward. The magnitude of $\mathrm{Z}$ is used to estimate trend significance. Trend slopes are obtained using the method of Sen (1968), as the median of all between-year differences between data values. MKT was used for the Czech, Slovak and Italian lakes.

For time series with a greater sampling frequency, the Seasonal Kendall Test (SKT) was applied. SKT is a refinement of $\mathrm{MKT}$ which is robust with respect to seasonality in time series, whereby data are first grouped into either monthly or quarterly blocks (Hirsch et al., 1982). $\mathrm{S}$ and $\operatorname{Var}(\mathrm{S})$ are calculated within each seasonal block and summed for all seasons to give full dataset statistics $S^{\prime}$ and $\operatorname{Var}\left(\mathrm{S}^{\prime}\right)$, which are then used to compute $\mathrm{Z}$. The estimate of $\operatorname{Var}\left(\mathrm{S}^{\prime}\right)$ was obtained using a modified procedure presented by Hirsch and Slack (1984), which provides a more robust significance test with respect to serial correlation. Trend slopes are again calculated according to the method of Sen (1968), as the median of between-year differences in values within each seasonal block. SKT has been identified as a suitable method for analysis of water quality data (Taylor and Loftis, 1989) and applied in a number of monitoring programmes, including ICP-Waters (Stoddard et al., 1999) and the United States Long Term Monitoring project (e.g.
Driscoll and van Dreason, 1993).

Given the close methodological similarities between MKT and SKT, the trend significances and slopes obtained at different sites should be approximately comparable. Both methods, however, are only able to detect monotonic trends within time series. As a consequence, and because the aim of this study was to assess whether recovery has occurred in response to falling levels of acid deposition, it was necessary to restrict analysis to the period at, or following, the peak in acid deposition. For this reason, and to limit the impact of varying monitoring periods at different sites, a 1980 start date was used for trend analyses at all sites with longer-term data. A significance threshold of $\mathrm{p} \leq 0.05$ was applied to both trend tests. A second threshold of $\mathrm{p} \leq 0.20$ was also used to identify weak, but potentially genuine, trends.

\section{Results}

For each variable, estimated slopes for all 56 sites are ranked (Fig. 2) in order to identify overall patterns of concentration change during the study period. Given the potential dominance of the 22 UK sites within this assessment, sites were also subdivided into six regions, for which median and percentile slopes were calculated (Table 2, Fig. 3). Due to the small number of Finnish and Norwegian sites in the dataset, these were combined with those in Sweden to form a single 'Scandinavia' region of 11 sites. Trend directions are also mapped in Fig. 4.

\section{NON-MARINE SULPHATE}

Clear decreases in surface water $\mathrm{xSO}_{4}$ concentrations have occurred throughout the areas of Europe included in this study, with significant $(\mathrm{p} \leq 0.05)$ declining trends at 38 sites and weak $(\mathrm{p} \leq 0.20)$ downward trends at a further 10 . The largest median decreases have occurred in Slovakia and the Czech Republic, with large and widespread decreases also observed in Scandinavia and Germany (with the exception of one site, Lange Bramke). In all four of these regions, median $\mathrm{xSO}_{4}$ reductions have exceeded -2.5 meq $\mathrm{l}^{-1} \mathrm{yr}^{-1}$. Significant downward trends are observed at all five Italian sites, but are smaller in magnitude (median $-1.0 \mathrm{meq}^{-1}$ $\left.\mathrm{yr}^{-1}\right)$. In the UK, although most sites have shown an overall decrease in $\mathrm{xSO}_{4}$, a period of relatively stable concentrations between 1988 and 1995 (Evans and Monteith, 2001) resulted in fewer sites showing significant downward trends. European trends in $\mathrm{SO}_{4}$ are discussed in further detail by Prechtel et al. (2001). 
Table 2. Summary of trends and median estimated concentration changes by region

\begin{tabular}{|c|c|c|c|c|c|c|c|}
\hline & Italy & Slovakia & a Czech $R$ & Germany & Scandinavia & $U K$ & All \\
\hline Number of sites & 5 & 5 & 6 & 7 & 11 & 22 & 56 \\
\hline \multicolumn{8}{|l|}{ ANC } \\
\hline Rising ( $\mathrm{p} \leq 0.05)$ & 2 & 4 & 5 & & 6 & 10 & 27 \\
\hline Rising $(\mathrm{p} \leq 0.20)$ & & & 1 & 1 & 3 & 4 & 9 \\
\hline Falling $(\mathrm{p} \leq 0.20)$ & 1 & 1 & & & & 2 & \\
\hline Falling $(\mathrm{p} \leq 0.05)$ & & & & 1 & & 1 & \\
\hline Median change $\left(\mu e q l^{-1} y r^{-1}\right)$ & +0.24 & +1.80 & +4.49 & +1.10 & +1.33 & +1.05 & +1.29 \\
\hline \multicolumn{8}{|l|}{ pH } \\
\hline Rising $(\mathrm{p} \leq 0.05)$ & 2 & 1 & 4 & 1 & 5 & 6 & 19 \\
\hline Rising ( $\mathrm{p} \leq 0.20)$ & & 2 & & & 1 & 3 & 6 \\
\hline Falling $(\mathrm{p} \leq 0.20)$ & 2 & 1 & & & & 1 & 4 \\
\hline Falling $(\mathrm{p} \leq 0.05)$ & & & & & 1 & 1 & 2 \\
\hline Median change ( $p H$ unit $y r$ & $\left.{ }^{1}\right)-0.001$ & +0.013 & +0.011 & -0.001 & +0.008 & +0.004 & +0.005 \\
\hline \multicolumn{8}{|l|}{$\mathrm{xSO}_{4}$} \\
\hline Rising $(\mathrm{p} \leq 0.05)$ & & & & 1 & & 1 & 2 \\
\hline Rising ( $\mathrm{p} \leq 0.20)$ & & & & & & 0 & \\
\hline Falling $(\mathrm{p} \leq 0.20)$ & & & 1 & & & 9 & 10 \\
\hline Falling $(\mathrm{p} \leq 0.05)$ & 5 & 5 & 4 & 6 & 11 & 7 & 38 \\
\hline Median change $\left(\mu e q l^{-1} y r^{-1}\right)$ & -1.00 & -4.17 & -3.47 & -2.60 & -2.76 & -1.10 & -1.92 \\
\hline \multicolumn{8}{|l|}{$\mathbf{C a}$} \\
\hline Rising $(\mathrm{p} \leq 0.05)$ & & & 1 & & & & 1 \\
\hline Rising ( $\mathrm{p} \leq 0.20)$ & 1 & & & & & & 1 \\
\hline Falling $(\mathrm{p} \leq 0.20)$ & 1 & & & & 2 & 6 & 9 \\
\hline Falling $(\mathrm{p} \leq 0.05)$ & 1 & 5 & 4 & 4 & 6 & 6 & 26 \\
\hline Median change $\left(\mu e q l^{-1} y r^{-1}\right)$ & -0.30 & -2.77 & -0.46 & -1.61 & -0.83 & -0.90 & -0.90 \\
\hline \multicolumn{8}{|l|}{$\mathrm{NO}_{3}$} \\
\hline Rising $(\mathrm{p} \leq 0.05)$ & 4 & & & 1 & 2 & 3 & 10 \\
\hline Rising $(\mathrm{p} \leq 0.20)$ & & & & 1 & & 3 & 4 \\
\hline Falling $(\mathrm{p} \leq 0.20)$ & 1 & 1 & & 2 & 2 & & 6 \\
\hline Falling $(\mathrm{p} \leq 0.05)$ & & 2 & 3 & 2 & 4 & & 11 \\
\hline Median change $\left(\mu e q l^{-1} y r^{-1}\right)$ & +0.54 & -0.78 & -0.72 & -0.61 & -0.04 & 0 & 0 \\
\hline \multicolumn{8}{|l|}{$\mathbf{A l} *$} \\
\hline Rising $(\mathrm{p} \leq 0.05)$ & & & 1 & 1 & & 2 & 4 \\
\hline Rising ( $\mathrm{p} \leq 0.20)$ & & & & & 1 & 2 & 3 \\
\hline Falling $(\mathrm{p} \leq 0.20)$ & 1 & 2 & & 2 & 4 & 2 & 11 \\
\hline Falling $(\mathrm{p} \leq 0.05)$ & 1 & & 5 & 2 & 1 & 4 & 13 \\
\hline Median change $\left(\mu g l^{-1} y r^{-1}\right)$ & -1.4 & +0.1 & -20.5 & -4.2 & -0.1 & +0.1 & -0.6 \\
\hline
\end{tabular}

\section{NITRATE}

Nitrate trends are highly variable among the study sites, with no evidence of consistent Europe-wide changes in concentrations since the 1980s. A substantial number of sites, mostly in low-deposition areas of the UK and Scandinavia, have near-zero $\mathrm{NO}_{3}$ trends as a result of continuously low surface water concentrations. The only 
(a) Acid Neutralising Capacity

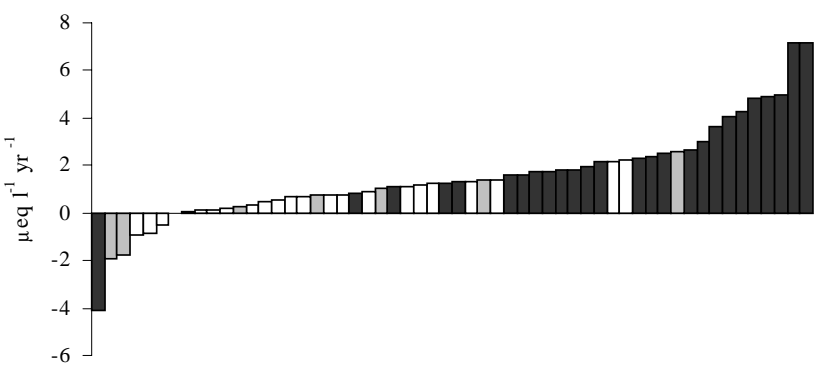

(b) $\mathrm{pH}$

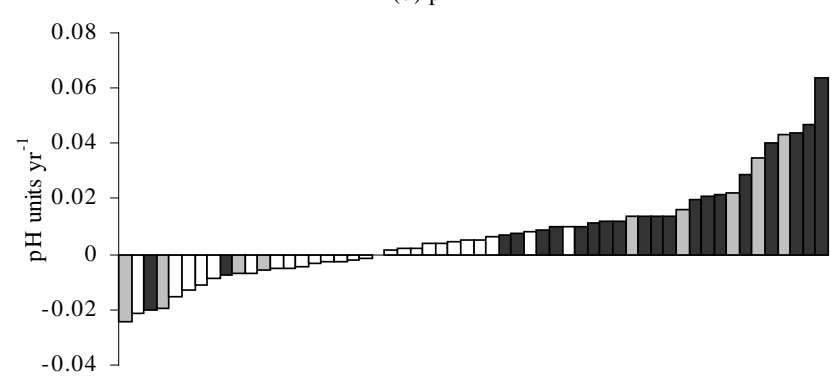

(c) Non-marine Sulphate

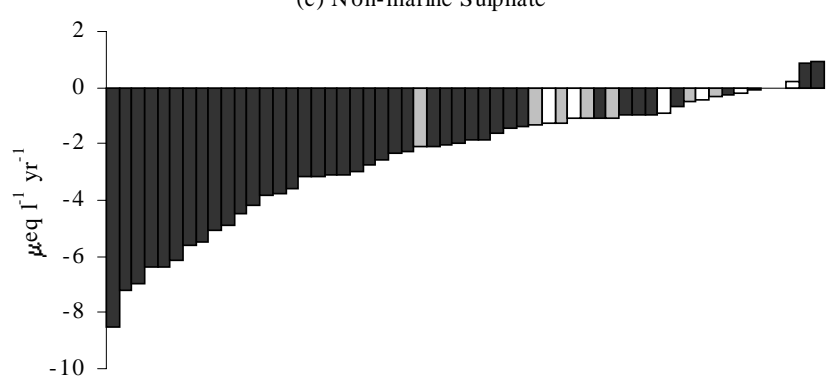

(d) Calcium

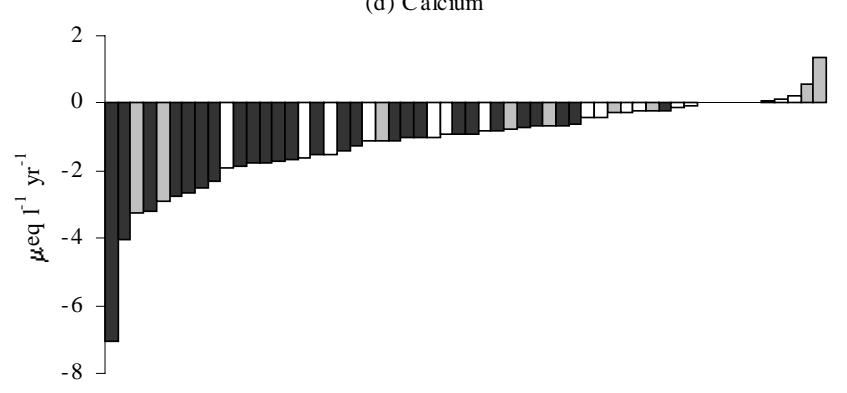

(e) Nitrate

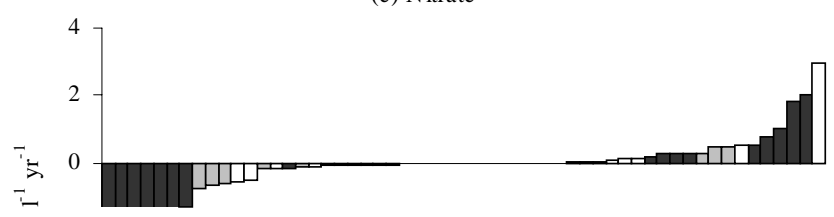

Fig. 2. Ranked trend slopes for all analysed surface waters (a) Acid Neutralising Capacity

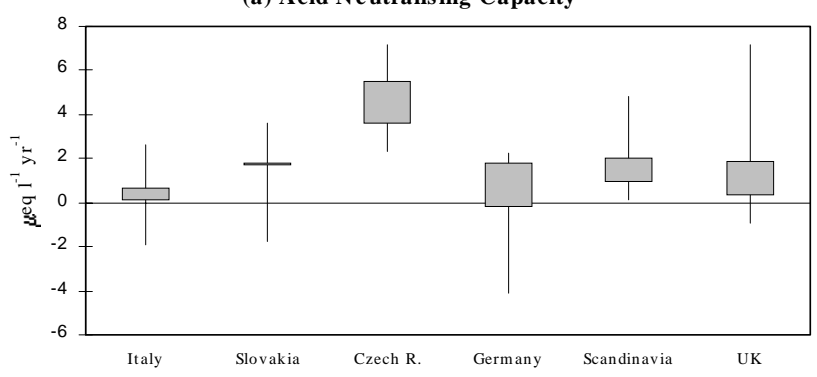

(b) $\mathbf{p H}$

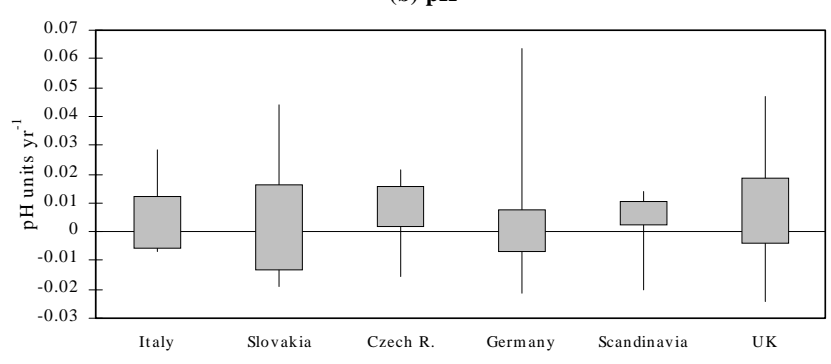

(c) Non-marine Sulphate

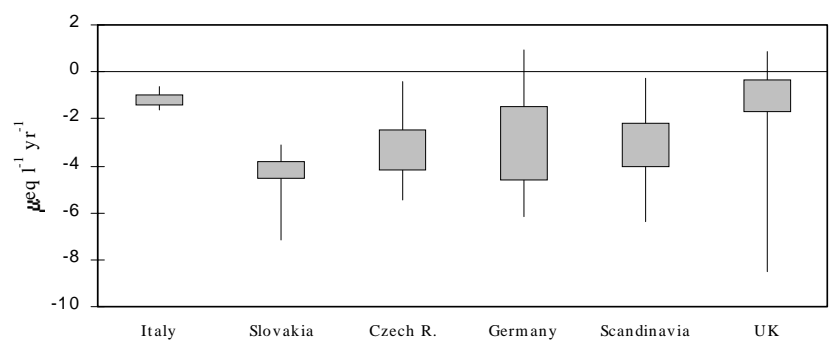

(d) Calcium

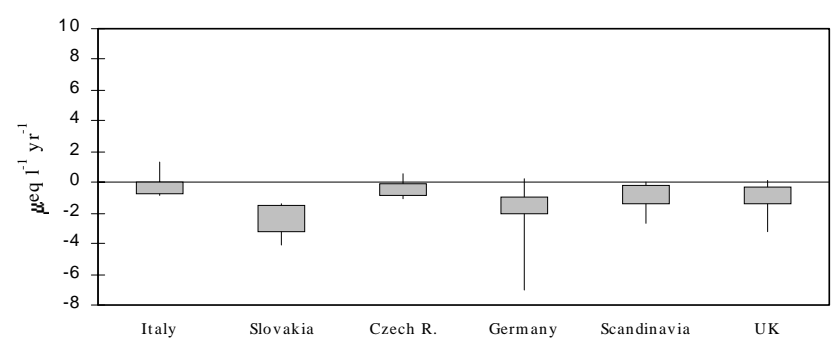

(e) Nitrate

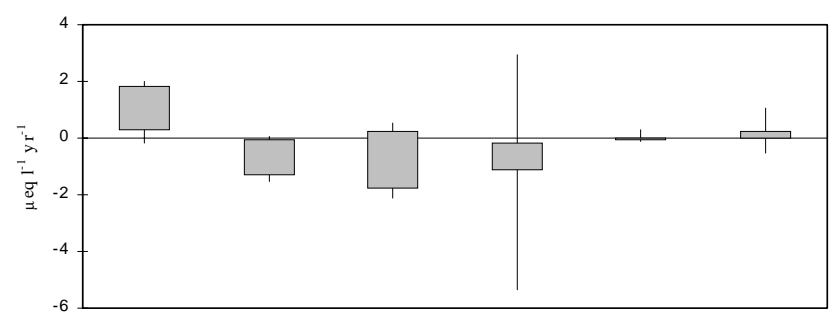

Fig. 3. Range of trend slopes observed within each region. Boxes represent interquartile range of slope estimates, lines show maximum and minimum observed slopes. Note that all slope estimates are included in calculation, regardless of significance. 

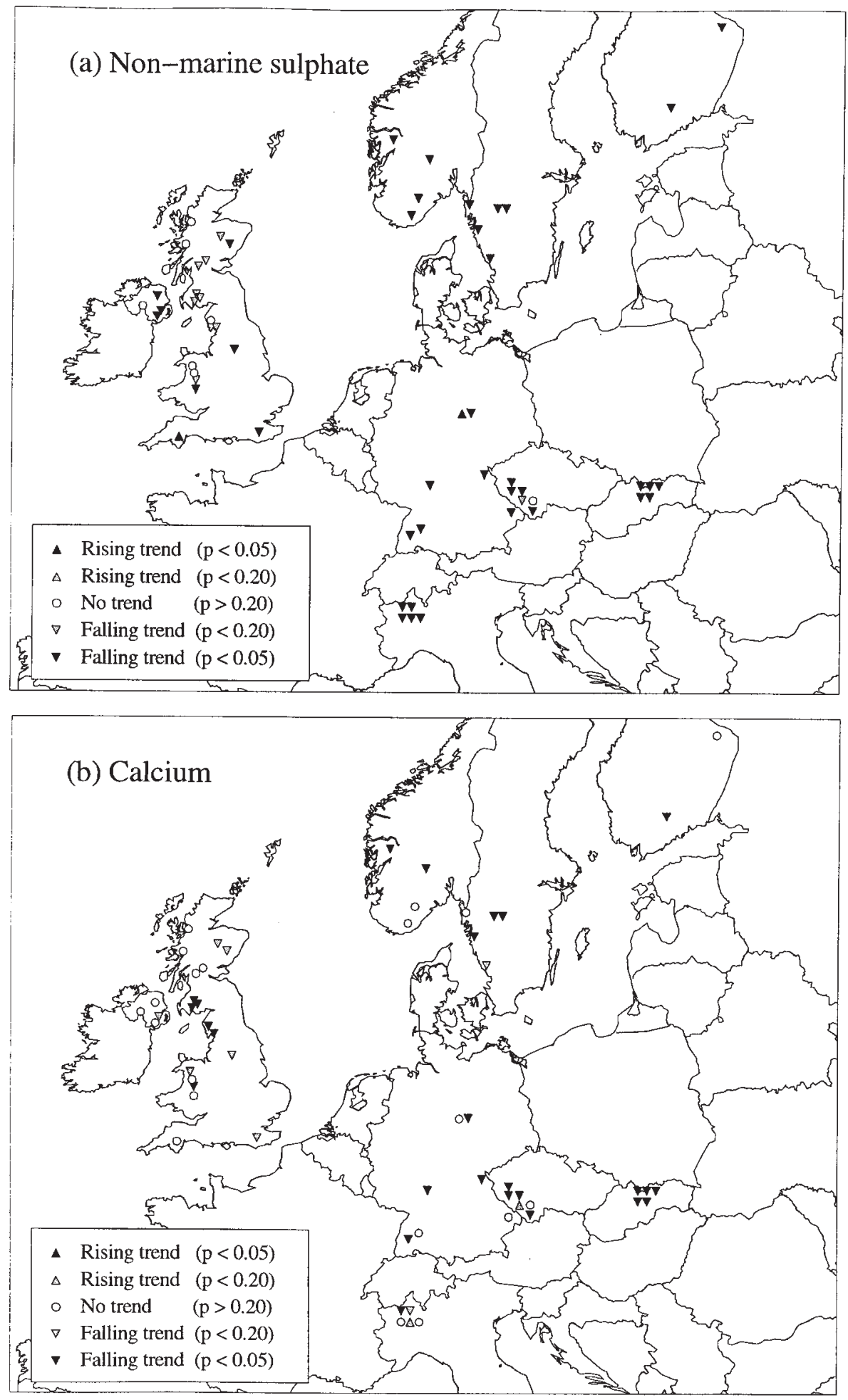

Fig. 4. Spatial distribution of observed trends

area with clear evidence of rising concentrations is Italy, where significant increases have occurred at four sites and may be indicative of decreasing catchment $\mathrm{N}$ retention (Mosello et al., 2001). A small number of sites in higherdeposition areas of the UK have also shown significant increases, but most trends here appear to result from a climate-related $\mathrm{NO}_{3}$ peak in 1996 (Evans and Monteith, 2001). The largest increase in $\mathrm{NO}_{3}$ occurred at Markungsgraben, following severe forest damage caused by a bark beetle infestation starting in 1993 (Alewell et al., 

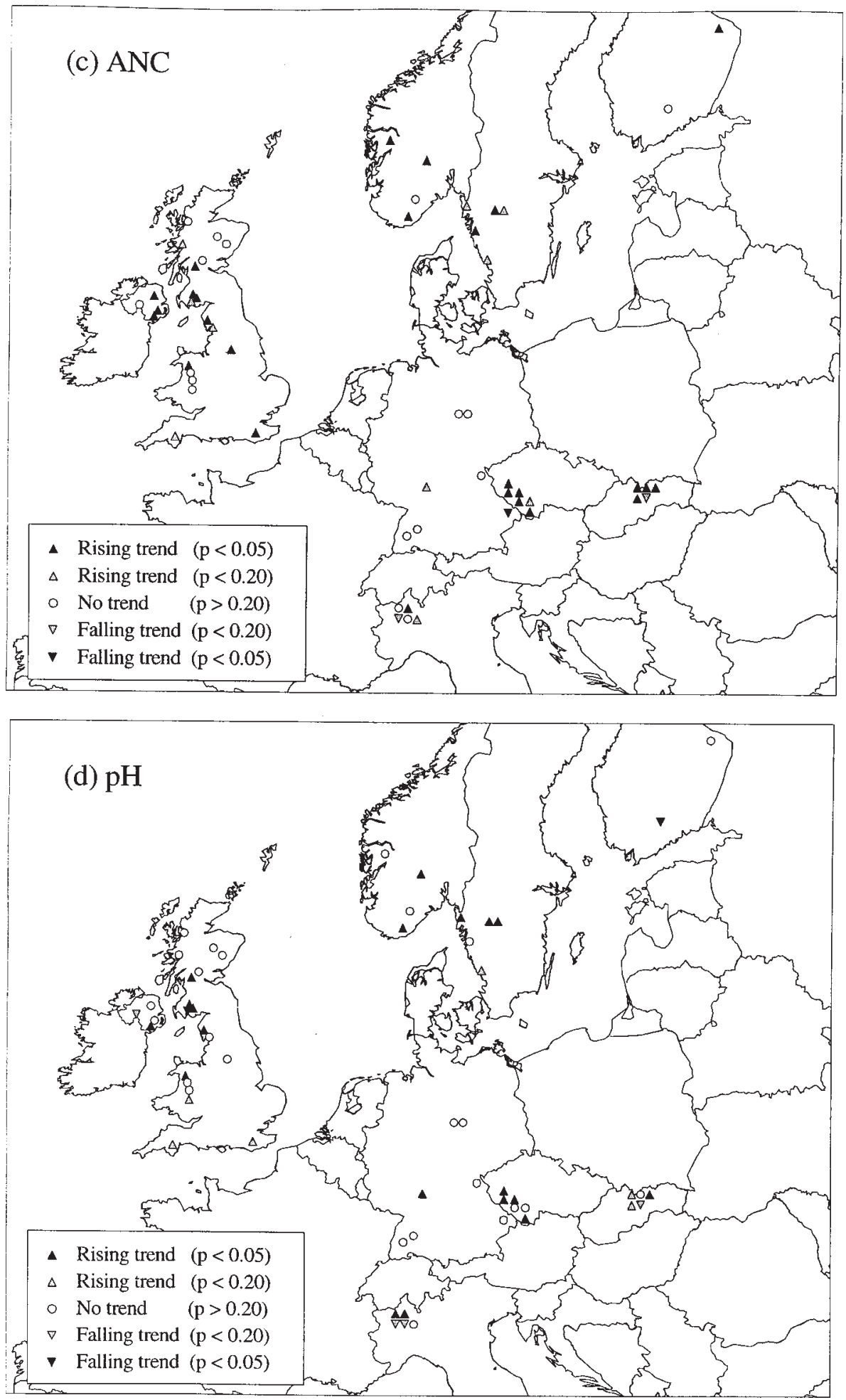

Fig. 4 (contd). Spatial distribution of observed trends

2001). Many sites in Central Europe (Germany, Slovakia and the Czech Republic), however, recorded decreases in $\mathrm{NO}_{3}$, probably reflecting reductions in $\mathrm{N}$ deposition during the 1990s (Verstreng and Støren, 2000; Barret et al., 2000).
Smaller but significant downward trends were observed at four sites in Scandinavia. European trends in $\mathrm{NO}_{3}$ are discussed in further detail by Wright et al. (2001). 


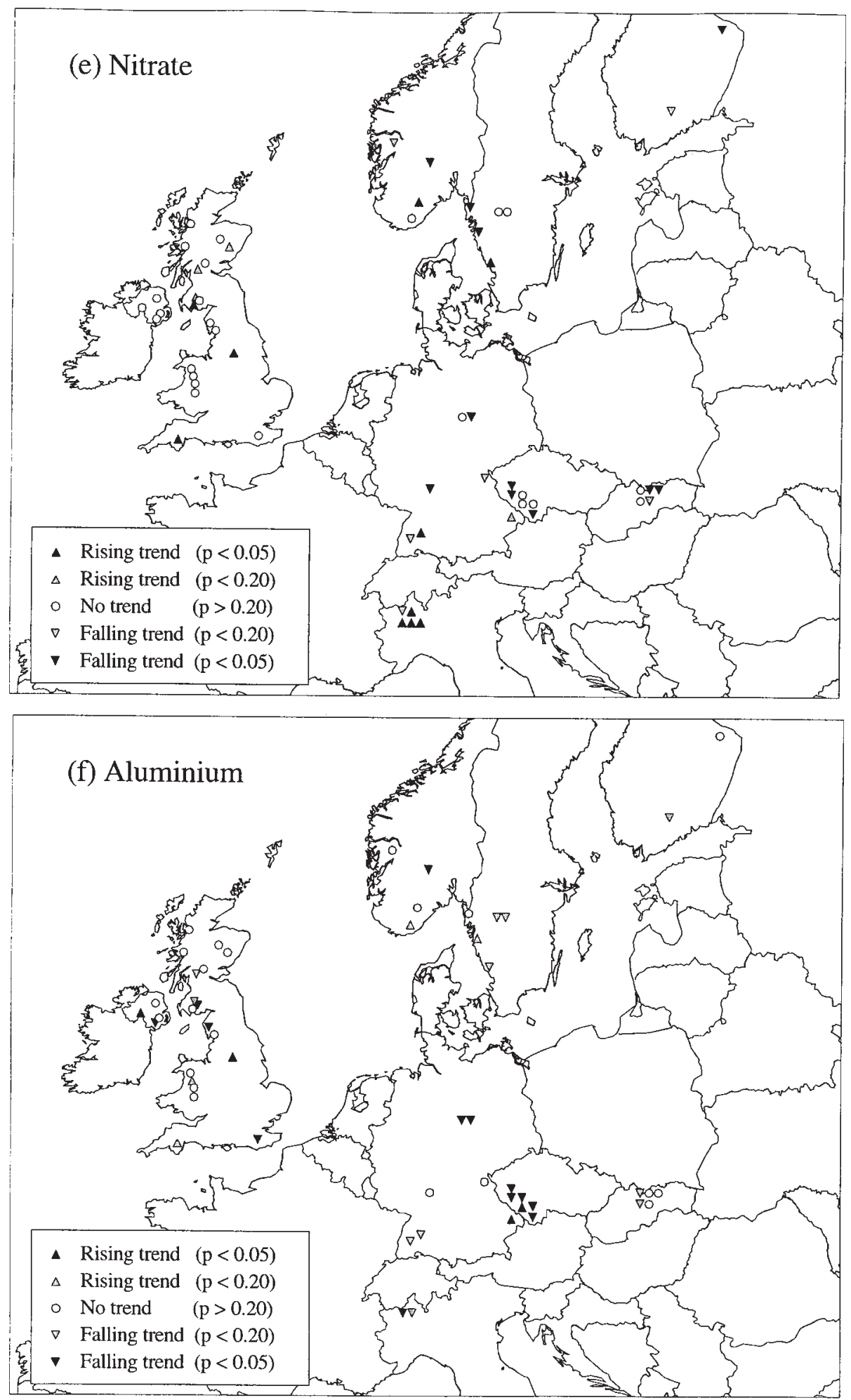

Fig. 4 (contd). Spatial distribution of observed trends

\section{ACID NEUTRALISING CAPACITY}

There is a clear tendency towards rising ANC in lakes and streams throughout the study regions; of the 56 sites, 27 exhibit significant rising trends, and weak increases are observed at a further nine. The majority of sites show increasing ANC in all regions except Germany, where only one weak rising trend is recorded (Table 2). In no region do more than two sites show an ANC decline and the only site 
at which ANC has decreased significantly is Markungsgraben in Germany, due to the $\mathrm{NO}_{3}$ pulse described above. The greatest median ANC increase (4.5 $\mu \mathrm{eq}^{-1} \mathrm{yr}^{-1}$ ) has been observed in the Czech Republic and the smallest $\left(0.7 \mu \mathrm{eq}^{-1} \mathrm{yr}^{-1}\right)$ in Italy; overall the median increase has been $1.3 \mu \mathrm{eq} \mathrm{l}^{-1} \mathrm{yr}^{-1}$.

\section{CALCIUM}

Changes in $\mathrm{Ca}$ appear to correspond closely to those in $\mathrm{xSO}_{4}$, with significant downward trends at 26 sites and weak downward trends at nine additional sites. The overall median trend slope of $-0.9 \mu \mathrm{eq}^{-1} \mathrm{yr}^{-1}$ is just under half of the median slope for $\mathrm{xSO}_{4}\left(-1.9 \mu\right.$ eq $\left.\mathrm{l}^{-1} \mathrm{yr}^{-1}\right)$, but substantial interregional variations are apparent, with much smaller proportional Ca reductions in the Czech Republic, and to a lesser extent Scandinavia and Italy, and larger proportional reductions in Slovakia, Germany and the UK. Observed decreases can be explained in part by reductions in $\mathrm{Ca}$ deposition, particularly in Central Europe, but at most sites a reduction in leaching from catchment soils is considered to be the main cause (discussed below).

\section{$\mathrm{pH}$}

Nineteen of the 56 sites exhibit significant rising trends in $\mathrm{pH}$ and another six show weak increases. Median slope estimates are positive for five regions, but narrowly negative in Germany. As for ANC, the results indicate widespread recovery, but fewer sites show increasing $\mathrm{pH}$ than show increasing ANC. The reasons for this apparent discrepancy are discussed below.

\section{ALUMINIUM}

Significant downward trends in Al have been observed at 13 sites and negative slopes at another 15 . Only four sites have shown significant rising trends. Although data are limited to two sites for Italy, results for all regions suggest a tendency towards declining $\mathrm{Al}$ concentrations (Figs. 3 and 4). Examination of individual regions shows a high degree of heterogeneity, however, with by far the largest decreases observed in the Czech Republic. At five of the Czech lakes, strong recovery from very acidic conditions has resulted in large reductions in $\mathrm{Al}\left(-13\right.$ to $\left.-34 \mu \mathrm{g} \mathrm{l}^{-1} \mathrm{yr}^{-1}\right)$. Trends in Slovakia are generally weak, possibly due to limited Al data for these sites. In Germany, most streams exhibit falling concentrations, but Markungsgraben is again an outlier with sharply rising $\mathrm{Al}$ concentrations correlated with the rise in $\mathrm{NO}_{3}$. In the UK, few trends are observed in $\mathrm{Al}$, but this apparent lack of change masks a major shift in speciation at many sites, from the toxic inorganic forms to non-toxic organic species (Evans and Monteith, 2001). Similar trends in Al species at the four Norwegian sites (SFT, 1999; Lydersen, 1998) indicate that this transition has also occurred in at least part of Scandinavia.

\section{Discussion}

Taking the 56 study sites as a whole, results provide clear evidence for recovery from acidification in terms of falling $\mathrm{xSO}_{4}$ concentrations, rising $\mathrm{ANC}$, rising $\mathrm{pH}$ and falling $\mathrm{Al}$ at a high proportion of sites. Decreases in $\mathrm{xSO}_{4}$ are particularly strong and widespread, confirming that surface waters have responded to reductions in anthropogenic $S$ deposition throughout the areas of Europe studied, although release of stored $\mathrm{S}$ from catchment soils may have damped this response in some regions, notably Germany (Alewell et al., 2001; Prechtel et al., 2001). With relatively little change in $\mathrm{NO}_{3}$ at most sites, $\mathrm{xSO}_{4}$ decreases have led to an overall reduction in acid anion concentrations, generating a range of chemical responses. Although qualitatively similar at the majority of sites, quantitative differences in trends can be identified both within and between regions.

As might be expected, the magnitude of ANC trend is negatively correlated with the sum of trends in $\mathrm{xSO}_{4}$ and $\mathrm{NO}_{3}$, although there is considerable scatter in this relationship (Fig. 5a; $\mathrm{R}^{2}=0.27, \mathrm{p}<0.0001$ ). A slope coefficient of -0.49 implies that, on average, approximately half of the observed reduction in $\left[\mathrm{xSO}_{4}+\mathrm{NO}_{3}\right]$ has translated into increased ANC. Clearly, therefore, part of the acid anion reduction has been balanced by changes in other ions and this is demonstrated by a strong positive correlation between $\Delta \mathrm{Ca}$ and $\left(\Delta \mathrm{xSO}_{4}+\Delta \mathrm{NO}_{3}\right)\left(\right.$ Fig. $\left.5 \mathrm{~b} ; \mathrm{R}^{2}=0.59, \mathrm{p}<0.0001\right)$. Over the timescales involved in this study, the primary mechanism of recovery is thought to be decreasing ionic strength, whereby reduced concentrations of mobile acid anions lead to reduced leaching of both acid cations ( $\mathrm{H}$ and inorganic $\mathrm{Al}$ ) and base cations from soils, and consequently to increases in ANC (Reuss and Johnson, 1986). Clearly, this process must involve all base cations to some extent, but a slope coefficient of 0.41 for $\Delta \mathrm{Ca} v \cdot\left(\Delta \mathrm{xSO}_{4}+\Delta \mathrm{NO}_{3}\right)$ suggests that $\mathrm{Ca}$ reductions alone can account for around $80 \%$ of the imbalance between acid anion reductions and ANC increases when considering the dataset as a whole (Fig. 6). Since ANC increases due to declining ionic strength can only occur while acid anion concentrations continue to fall, longer term recovery must involve an increase in soil base saturation, with base cations from weathering and deposition replacing $\mathrm{H}$ and $\mathrm{Al}$ on exchange sites (Galloway et al., 1983). However, such a base saturation increase is neither 

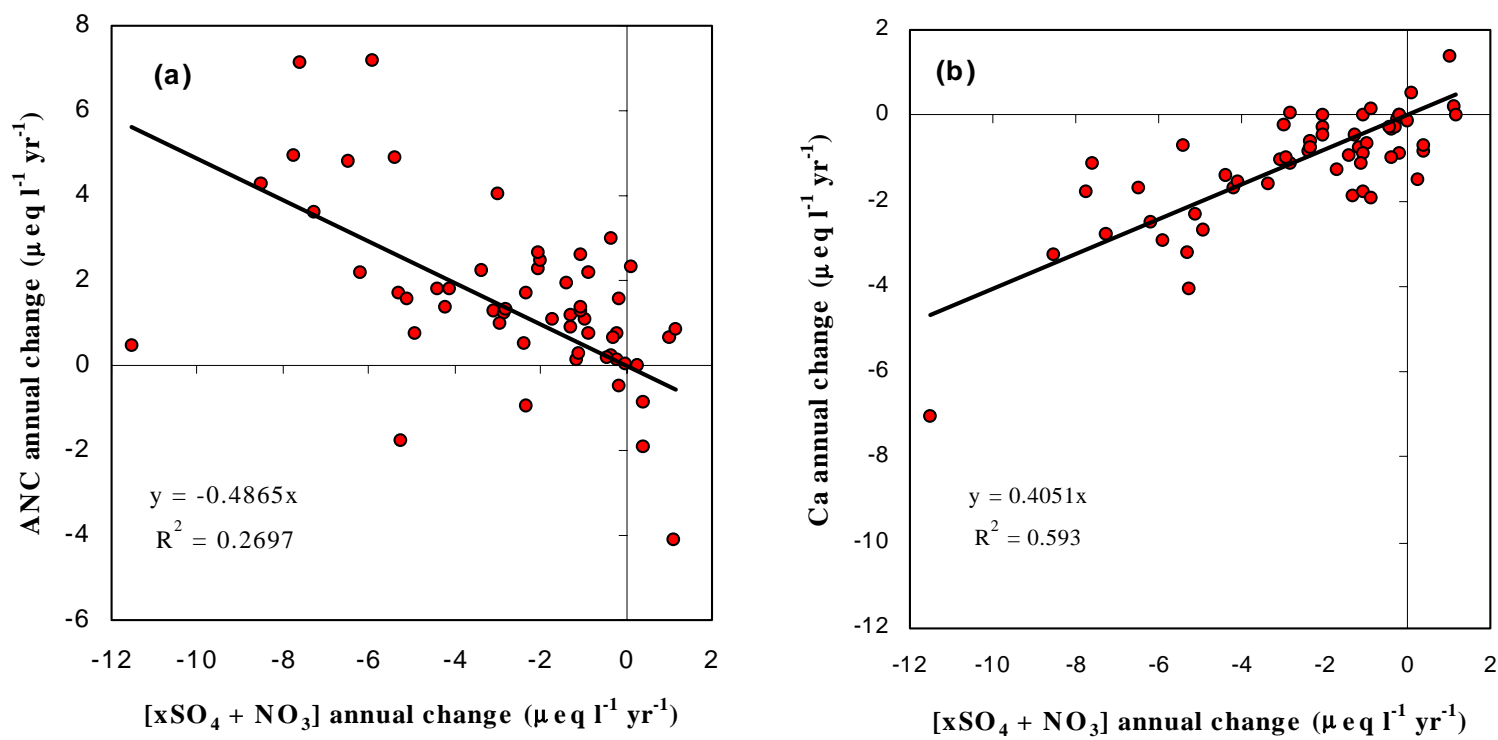

Fig. 5. Relationships between trend slopes for $\mathrm{ANC}, \mathrm{Ca}$ and $\left[\mathrm{xSO}_{4}+\mathrm{NO}_{3}\right]$

required nor implied by the short-term surface water trends observed. If present or future acid anion deposition continues to outstrip base cation supply, soil base saturation may continue to fall at some sites.

As noted earlier, the generalised relationship observed between acid anion and base cation changes conceals significant inter-regional variation, with the Czech Republic and Scandinavia showing a proportionally large ANC response to falling acid anion concentrations, and other areas (notably Germany) relatively small ANC responses. This variability can be linked to the buffering capacity of catchment soils; at the highly impacted Czech sites, for example, soils with a severely depleted base saturation have little capacity to buffer changes in acid anions and most of the decrease in acid anions has been accompanied by decreases in acid cations. At poorly buffered or severely depleted sites, therefore, $\triangle \mathrm{ANC}$ will tend towards $\left(\Delta \mathrm{xSO}_{4}\right.$ $+\Delta \mathrm{NO}_{3}$ ), whereas at sites where soil base cations are able to neutralise fully incoming acidity, $\triangle \mathrm{ANC}$ will tend towards zero (Henriksen et al., 1986). At the latter extreme, the absence of ANC 'recovery' is thus due to the absence of past freshwater acidification.

The smaller proportion of sites showing increases in $\mathrm{pH}$ compared to the proportion at which ANC has risen (Table 2) appears to result from a number of factors. In part it is a function of the logistic relationship between $\mathrm{ANC}$ and $\mathrm{pH}$, with $\mathrm{pH}$ changes smaller, and harder to detect, relative to changes in ANC at more alkaline sites. However, discrepancies between $\mathrm{ANC}$ and $\mathrm{pH}$ trends are also observed at some acidic sites. At these sites, ANC increases are comprised both of a decrease in $\mathrm{H}$ ion (i.e. an increase in
$\mathrm{pH}$ ) and a decrease in inorganic $\mathrm{Al}$ (Fig. 6). Consequently, trends in each acid cation may be weaker than the trend in ANC. In addition, it appears that in some regions of Europe, $\mathrm{pH}$ recovery may have been suppressed by increases in organic acidity. These increases, inferred from rising trends in DOC, are particularly evident in the UK (Evans and Monteith, 2001) and are also observed at a number of streams in Scandinavia. Although data are not available for most other regions, rising trends in chemical oxygen demand

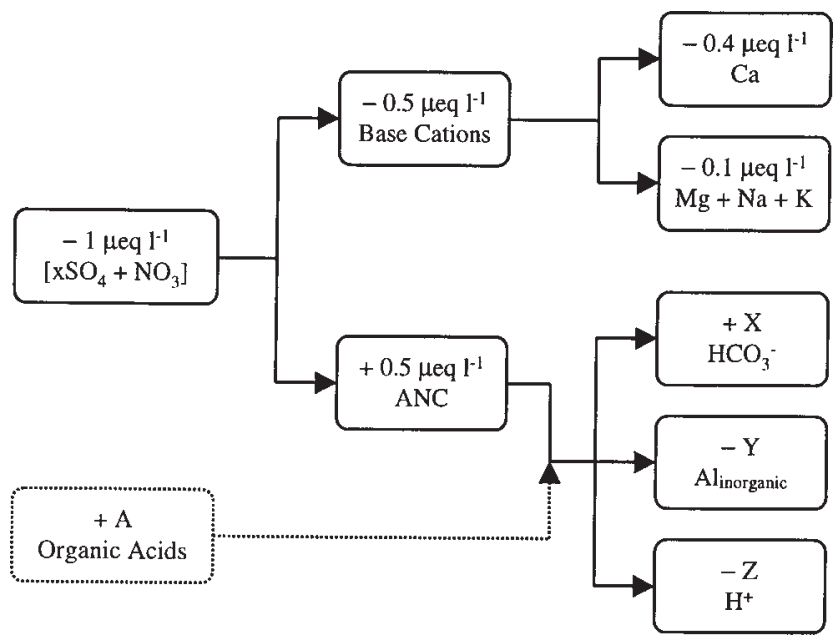

Fig. 6. Schematic view of changes in water chemistry caused by changes in acid deposition. Values given are an 'average' case based on trend analyses of the RECOVER:2010 sites, and will vary from site to site. Organic acid increases, observed in the UK and Scandinavia, are assumed here to have occurred independently of reductions in acid deposition. In the scheme given, $X+Y+Z=$ $\triangle A N C-A$. 
at lakes in the Bohemian Forest and Tatra Mountains (Kopácek, unpublished data) suggest that similar changes may have occurred here. Increases in organic acidity, while lowering $\mathrm{pH}$, do not affect $\mathrm{ANC}$ and can in part, therefore, account for the weaker observed increases in $\mathrm{pH}$.

The evidence from this study of recovery trends in freshwater chemistry and of the importance of base cation changes in regulating this recovery, largely supports that of previous European-scale assessments by Stoddard et al. (1999) and Skjelkvåle et al. (2000). Because the recovery trends continue through the 1990s, the longer records used here generally result in a more consistent and stronger pattern. This is particularly true for the UK, where both previous studies found little evidence of recovery; the new data included in this study suggest that $\mathrm{xSO}_{4}$ is declining and $\mathrm{ANC}$ and $\mathrm{pH}$ increasing, at rates comparable with those observed elsewhere in Europe. These results thus emphasise the value of sufficiently long datasets in distinguishing longterm changes from short-term (e.g. climatic) fluctuations. The finding of Stoddard et al. (1999) that European surface water trends shifted from falling base cation concentrations and largely stable ANC in the 1980s toward stable base cations and rising ANC in the 1990s, implying that base cation supplies might now exceed acid inputs, was not widely observed at sites in this study.

The results of this study also demonstrate that, whilst some general inferences can be drawn regarding the nature of chemical change, spatial heterogeneity cannot be ignored. For example, the four 'Central European' areas in this study (Northern Italy, Slovakia, the Czech Republic and Germany) have exhibited substantially differing trends over the last two decades despite their relative proximity. This spatial variability is by no means surprising given that the 23 sites in this region comprise both lakes and streams and a wide range of deposition, topography, vegetation and geological sensitivity, confirming the need for care when extrapolating from individual sites to regional and continental scales.

\section{Summary and conclusions}

A number of general patterns of chemical change can be clearly identified from the 56 European long-term monitoring datasets analysed within this study:

- Non-marine $\mathrm{SO}_{4}$ concentrations have fallen at the majority of sites and in all regions. Surface waters throughout the studied areas of Europe have, therefore, clearly responded to reductions in $\mathrm{S}$ emissions since the 1980s. However Prechtel et al. (2001) show that reductions in surface water $\mathrm{SO}_{4}$ have often been significantly smaller than those in deposition, due to the release of $\mathrm{S}$ stored in catchment soils.

- Falling surface water $\mathrm{xSO}_{4}$ has led to widespread improvements in ANC. Increases in ANC have commonly been smaller than decreases in $\mathrm{xSO}_{4}$, however, due to compensating changes in other ions.

- Much of the imbalance between $\mathrm{xSO}_{4}$ reductions and ANC recovery can be explained by widespread decreases in $\mathrm{Ca}$. The magnitude of $\mathrm{Ca}$ reductions and their impact on ANC, varies considerably between regions, for example having little impact in the Czech Republic, but severely limiting ANC recovery in Germany.

- Increases in $\mathrm{pH}$, although largely corresponding to those in ANC, have tended to be somewhat weaker, since part of the ANC increase has been comprised of reductions in inorganic $\mathrm{Al}$ rather than in $\mathrm{H}$ ion. Increases in organic acidity, which do not influence ANC, have also suppressed $\mathrm{pH}$ recovery at a significant number of sites, particularly in the UK.

- Consistent trends were not observed for $\mathrm{NO}_{3}$. Whilst concentrations have generally fallen in the Czech Republic, Slovakia and Germany, a substantial number of rising trends were observed in Italy and the UK. Overall, therefore, there is little evidence to suggest either a widespread response to falling $\mathrm{N}$ deposition, or a general increase in catchment $\mathrm{N}$ leakage.

- Few sites appear as clear outliers with respect to chemical trends. An exception is Markungsgraben, in Germany, where the elevated $\mathrm{NO}_{3}$ leaching and reacidification caused by insect damage underlines the continued susceptibility of many sensitive ecosystems to biological or climatic 'shocks' under current levels of deposition loading.

Overall, the long-term monitoring data presented here provide clear evidence that reductions in the emission of acidifying pollutants during the last two decades have had a significant beneficial impact on water quality across a wide range of countries and ecosystems within Europe. These improvements in water quality nonetheless represent only a partial recovery of these systems, many of which remain acidic. Given negative feedback processes such as $\mathrm{S}$ adsorption/desorption and soil cation exchange, chemical recovery has not been instantaneous and it is likely that biological recovery will lag further behind improvements in water quality. Future emissions reductions agreed under the Gothenburg Protocol should increase both the magnitude and rapidity of change, but it may be many years before European surface waters recover fully from acidification. 


\section{Acknowledgements}

This project was financially supported by the Commission of European Communities RECOVER:2010 project (EVK1CT-1999-00018). Support for national monitoring programmes was provided by the German Ministry of Education and Research (grant no. PT BEO 51-0339476), the Bavarian State Office for Water Management and the Forest Research Institute of Lower Saxony; the United Kingdom Department of the Environment, Transport and the Regions (Contract No. EPG 1/3/92) and the Environment and Heritage Service, Northern Ireland; the Norwegian National Programme for Monitoring of Long-Range Transported Polluted Air and Precipitation (SFT, 2000); the Swedish Department of Environmental Assessment (SLU) (www.ma.slu.se); the Finnish Environment Institute; the Joint Commission for the Protection of Water on the border between Italy and Switzerland (Commissione Internazionale per la Protezione delle Acque Italo-Svizzere); the Grant Agency of the Czech Republic (Project No. 206/00/0063) and the Commission of European Communities EMERGE project (EVK1-CT-1999-00032). Data for Villingen and Schluchsee were taken from Armbruster (1998). We would like to thank Martin Forsius, Stefan Löfgren, Brit-Lisa Skjelkvåle and Evzen Stuchlik for provision of data to this study, and Beate Gannon and Rachel Helliwell for assistance with maps.

\section{References}

Alewell, C., Armbruster, M., Bittersohl, J., Evans, C.D., Meesenburg, H., Moritz, K. and Prechtel, A., 2001. Are there signs of aquatic recovery after two decades of reduced acid deposition in the low mountain ranges of Germany? Hydrol. Earth Syst. Sci., 5, 367-378.

Armbruster, M., 1998. Zeitliche Dynamik der Wasser- und Elementflüsse in Waldökosystemen. Freiburger Bodenkundliche Abhandlungen, 38, 1-301.

Barrett, K., Schaug, J., Bartanova, A., Semb, A., Hjellbrekke, A.G. and Hanssen, J.E., 2000. A Contribution from CCC to the reevaluation of the observed trends in sulphur and nitrogen in Europe 1978-1998. EMEP Chemical Co-ordinating Centre, Norwegian Institute for Air Research, Kjeller, Norway.

Christophersen, N., Robson, A., Neal, C., Whitehead, P.G., Vigerust, B. and Henriksen, A., 1990. Evidence for long-term deterioration of streamwater chemistry and soil acidification at the Birkenes catchment, Southern Norway. J. Hydrol., 116, 63-76.

Driscoll, C.T. and van Dreason, R., 1993. Seasonal and long-term patterns in the chemistry of Adirondack lakes. Water Air Soil Pollut., 67, 319-344.

Evans, C.D. and Monteith, D.T., 2001. Chemical trends at lakes and streams in the UK Acid Waters Monitoring Network, 19882000. Evidence for recent recovery at a national scale. Hydrol. Earth Syst. Sci., 5, 351-366.

Evans, C.D., Harriman, R., Monteith, D.T. and Jenkins, A., 2001. Assessing the suitability of acid neutralising capacity as a measure of long-term trends in acid waters based on two parallel datasets. Water Air Soil Pollut., (in press).
EU, 2000. Water Framework Directive (2000/86/EEC), European Union, Brussels.

Galloway, J.N., Norton, S.A. and Church, M.R., 1983. Freshwater acidification from atmospheric deposition of sulfuric acid: A conceptual model. Environ. Sci. Technol., 16, 541A-545A.

Harriman, R., Morrison, B.R.S., Birks, H.J.B., Christie, A.E.G., Collen, P. and Watt, A.W., 1995. Long-term chemical and biological trends in Scottish streams and lochs. Water Air Soil Pollut., 85, 701-706.

Henriksen, A., Dickson, W. and Brakke, D.F., 1986. Estimates of critical loads to surface waters. In: Critical Loads for Sulphur and Nitrogen, J. Nilsson (Ed.), 87-120. Nordic Council of Ministers, Copenhagen.

Hirsch, R.M. and Slack, J.R., 1984. A non-parametric test for seasonal data with serial dependence. Water Resour. Res., 20, 727-732.

Hirsch, R.M., Slack, J.R. and Smith, R.A., 1982. Techniques of trend analysis for monthly water quality data. Water Resour. Res., 18, 107-121.

Kendall, M.G. 1975. Rank Correlation Methods. Charles Griffin, London.

Kopácek, J., Hejzlar, J., Stuchlík, E., Fott, J. and Veselý, J., 1998. Reversibility of acidification of mountain lakes after reduction in nitrogen and sulphur emissions in Central Europe. Limnol. Oceanogr., 43, 357-361.

Kopácek, J., Stuchlík, E., Veselý, J., Schaumburg, J., Anderson, I.C., Fott, J., Hejzlar, J. and Vrba, J., 2001. Hysteresis in reversal of Central European mountain lakes from atmospheric acidification. Water Air Soil Pollut., (in press).

Lydersen, E., 1998. Humus and acidification. In: Aquatic Humic Substances, Ecology and Biogeochemistry, Ecological Studies, D.O. Hessen and L. Tranvik (Eds.), 133, 63-92. Springer, Berlin.

Mann, H.B., 1945. Non-parametric test against trend. Econometrica, 13, 245-259.

Mannio, J. and Vuorenmaa, J., 1995. Regional monitoring of lake acidification in Finland. Water Air Soil Pollut., 85, 571-576.

Moldan, F., Wright, R.F., Lofgren, S., Forsius, M. and Skjelkvåle, B.L., 2001. Long-term changes in acidification and recovery at nine calibrated catchments in Norway, Sweden and Finland. Hydrol. Earth Syst. Sci., 5, 339-349.

Monteith, D.T. and Evans, C.D. (Eds.), 2000. The UK Acid Waters Monitoring Network: 10 Year Report. ENSIS Publishing, London, 363 pp.

Mosello, R., Marchetto, A., Brizzio, M.C., Rogora, M. and Tartari, G.A., 2000. Results from the Italian participation in the International Co-operative Programme on Assessment and Monitoring of Acidification of Rivers and Lakes (ICP Waters). J. Limnol., 59, 47-54.

Mosello, R., Calderoni, A., Marchetto, A., Brizzio, M.C., Rogora, M., Passera, S. and Tartari, G.A., 2001. Nitrogen budget of Lago Maggiore: the relative importance of atmospheric deposition and catchment sources. J. Limnol., (in press).

Prechtel, A., Alewell, C., Armbruster, M., Bittersohl, J., Cullen, J.M., Evans, C.D., Helliwell, R., Kopácek, J., Marchetto, A., Matzner, E., Meesenburg, H., Moldan, F., Moritz, K., Veselý, J. and Wright, R.F., 2001. Response of sulphur dynamics in European catchments to decreasing sulphate deposition. Hydrol. Earth Syst. Sci., 5, 311-325.

Reuss, J.O. and Johnson, D.W., 1986. Acid deposition and the acidification of soils and waters. In: Ecological Studies, 59, 199 pp. Springer, New York.

Reynolds, B., Renshaw, M., Sparks, T.H., Crane, S., Hughes, S., Brittain, S.A. and Kennedy, V.H., 1997. Trends and seasonality in stream water chemistry in two moorland catchments of the Upper River Wye, Plynlimon. Hydrol. Earth Syst. Sci., 1, 571581. 
Rodhe, H., Grennfelt, P., Wisniewski, J., Ågren, C., Bengtsson, G., Johansson, K., Kauppi, P., Kucera, V., Rasmussen, L., Rosseland, B., Schotte, L. and Selldén, G., 1995. Acid Reign '95 - Conference Summary Statement. Water Air Soil Pollut., 85, $1-14$

Rogora, M., Marchetto, A. and Mosello, R., 2001. Trends in the chemistry of atmospheric deposition and surface waters in Lago Maggiore watershed. Hydrol. Earth Syst. Sci., 5, 379-390.

Sen, P.K., 1968. Estimates of the regression coefficient base on Kendall's Tau. J. Amer. Statis. Assn., 63, 1379-1389.

SFT, 1999. Overvåking av langtransportert forurenset luft og nedbor. Årsrapport 1998. Statlig program for forurensningsovervåking Rapport 781/99, Statens forurensningstilsyn, Oslo, Norway.

SFT, 2000. Overvåking av langtransportert forurenset luft og nedbør. Årsrapport - Effekter 1999. Statlig program for forurensningsovervåking Rapport Statens forurensningstilsyn, Oslo, Norway. 198 pp.

Skjelkvåle, B.L., Wright, R.F. and Henriksen, A., 1998. Norwegian lakes show widespread recovery from acidification; results from national surveys of lakewater chemistry 1986-1997. Hydrol. Earth Syst. Sci., 2, 555-562.

Skjelkvåle, B.L., Andersen, T., Halvorsen, G.A., Raddum, G.G., Heegaard, E., Stoddard, J. and Wright, R.F., 2000. The twelve year report: Acidification of surface water in Europe and North America; Trends, biological recovery and heavy metals. Convention on Long-Range Transboundary Air Pollution, International Co-operative Programme on Assessment and Monitoring of Acidification of Rivers and Lakes, Norwegian Institute for Water Research, Oslo, $115 \mathrm{pp}$.

Skjelkvåle, B.L., Mannio, J., Wilander, A. and Andersen, T., 2001. Recovery from acidification of lakes in Finland, Norway and Sweden, 1990-1999. Hydrol. Earth Syst. Sci., 5, 327-337.
Soulsby, C., Turnbull, D., Hirst, D., Langan, S.J. and Owen, R., 1997. Reversibility of stream acidification in the Cairngorm region of Scotland. J. Hydrol., 195, 291-311.

Stoddard, J.L., Jeffries, D.S., Lükewille, A., Clair, T.A., Dillon, P.J., Driscoll, C.T., Forsius, M., Johannessen, M., Kahl, J.S., Kellogg, J.H., Kemp, A., Mannio, J., Monteith, D., Murdoch, P.S., Patrick, S., Rebsdorf, A., Skjelkvåle, B.L., Stainton, M.P., Traaen, T., van Dam, H., Webster, K.E., Wieting, J. and Wilander, A., 1999. Regional trends in aquatic recovery from acidification in North America and Europe. Nature, 401, 575578.

Taylor, C.H. and Loftis, J.C., 1989. Testing for trend in lake and ground water quality time series. Water Res. Bull., 25., 715-726.

UN-ECE, 1999. The 1999 Protocol to Abate Acidification, Eutrophication and Ground-level Ozone. Document ECE/ EB.AIR/67, United Nations Economic Commission for Europe, New York and Geneva.

Verstreng, V. and Støren, E., 2000. Analysis of UN ECE/EMEP emission data. MSC-W Status Report 2000. Norwegian Meteorological Institute, Oslo.

Veselý, J., Hruška, J., Norton, S.A. and Johnson, C.E., 1998. Trends in the chemistry of acidified Bohemian lakes from 1984 to 1995: I. Major solutes. Water Air Soil Pollut, 108, 107-127.

Wilander, A. and Lundin, L., 1999. Recovery of surface waters and forest soils in Sweden. In: Recovery from Acidification in the Natural Environment: Present Knowledge and Future Scenarios (P. Warfvinge and E. Bertills (Eds.)). Swedish Environmental Protection Agency, Report 5034, Stockholm, 96 pp.

Wright, R.F., Alewell, C., Cullen, J.M., Evans, C.D., Marchetto, A., Moldan, F., Prechtel, A. and Rogora, M., 2001. Trends in nitrogen deposition and leaching in acid-sensitive streams in Europe. Hydrol. Earth Syst. Sci., 5, 329-310. 


\section{Appendix I Sites used in European trend analysis}

\begin{tabular}{|c|c|c|c|c|c|c|c|}
\hline Site & Country & Latitude & Longitude & Start date & End date & Type & Mean ANC $\left(\right.$ meql $\left.^{-1}\right)$ \\
\hline 1. Loch Coire nan Arr & UK (Scotland) & $57^{\circ} 25^{\prime} \mathrm{N}$ & $5^{\circ} 39^{\prime} \mathrm{W}$ & 1988 & 2000 & Lake & 42 \\
\hline 2. Allt a'Mharcaidh & UK (Scotland) & $57^{\circ} 07^{\prime} \mathrm{N}$ & $3^{\circ} 50^{\prime} \mathrm{W}$ & 1988 & 2000 & Stream & 46 \\
\hline 3. Allt na Coire nan Con & UK (Scotland) & $56^{\circ} 45^{\prime} \mathrm{N}$ & $5^{\circ} 36^{\prime} \mathrm{W}$ & 1988 & 2000 & Stream & 35 \\
\hline 4. Lochnagar & UK (Scotland) & $56^{\circ} 57^{\prime} \mathrm{N}$ & $3^{\circ} 13^{\prime} \mathrm{W}$ & 1988 & 2000 & Lake & 3 \\
\hline 5. Loch Chon & UK (Scotland) & $56^{\circ} 12^{\prime} \mathrm{N}$ & $4^{\circ} 32^{\prime} \mathrm{W}$ & 1988 & 2000 & Lake & 23 \\
\hline 6. Loch Tinker & UK (Scotland) & $56^{\circ} 13^{\prime} \mathrm{N}$ & $4^{\circ} 30^{\prime} \mathrm{W}$ & 1988 & 2000 & Lake & 54 \\
\hline 7. Round Loch of Glenhead & UK (Scotland) & $55^{\circ} 05^{\prime} \mathrm{N}$ & $4^{\circ} 25^{\prime} \mathrm{W}$ & 1988 & 2000 & Lake & -2 \\
\hline 8. Loch Grannoch & UK (Scotland) & $55^{\circ} 00^{\prime} \mathrm{N}$ & $4^{\circ} 16^{\prime} \mathrm{W}$ & 1988 & 2000 & Lake & -27 \\
\hline 9. Dargall Lane & UK (Scotland) & $55^{\circ} 04^{\prime} \mathrm{N}$ & $4^{\circ} 26^{\prime} \mathrm{W}$ & 1988 & 2000 & Stream & 9 \\
\hline 10. Scoat Tarn & UK (England) & $54^{\circ} 28^{\prime} \mathrm{N}$ & $3^{\circ} 17^{\prime} \mathrm{W}$ & 1988 & 2000 & Lake & -14 \\
\hline 11. Burnmoor Tarn & UK (England) & $54^{\circ} 25^{\prime} \mathrm{N}$ & $3^{\circ} 15^{\prime} \mathrm{W}$ & 1988 & 2000 & Lake & 49 \\
\hline 12. River Etherow & UK (England) & $53^{\circ} 29^{\prime} \mathrm{N}$ & $1^{\circ} 49^{\prime} \mathrm{W}$ & 1988 & 2000 & Stream & 31 \\
\hline 13. Old Lodge & UK (England) & $51^{\circ} 02^{\prime} \mathrm{N}$ & $0^{\circ} 04^{\prime} \mathrm{E}$ & 1988 & 2000 & Stream & -17 \\
\hline 14. Narrator Brook & UK (England) & $50^{\circ} 30^{\prime} \mathrm{N}$ & $4^{\circ} 01^{\prime} \mathrm{W}$ & 1991 & 2000 & Stream & 18 \\
\hline 15. Llyn Llagi & UK (Wales) & $53^{\circ} 00^{\prime} \mathrm{N}$ & $4^{\circ} 00^{\prime} \mathrm{W}$ & 1988 & 2000 & Lake & 12 \\
\hline 16. Llyn Cwm Mynach & UK (Wales) & $53^{\circ} 47^{\prime} \mathrm{N}$ & $3^{\circ} 57^{\prime} \mathrm{W}$ & 1988 & 2000 & Lake & 9 \\
\hline 17. Afon Hafren & UK (Wales) & $52^{\circ} 28^{\prime} \mathrm{N}$ & $3^{\circ} 42^{\prime} \mathrm{W}$ & 1988 & 2000 & Stream & 2 \\
\hline 18. Afon Gwy & UK (Wales) & $52^{\circ} 27^{\prime} \mathrm{N}$ & $3^{\circ} 42^{\prime} \mathrm{W}$ & 1991 & 2000 & Stream & 14 \\
\hline 19. Beaghs Burn & UK (N.Ireland) & $55^{\circ} 07^{\prime} \mathrm{N}$ & $6^{\circ} 05^{\prime} \mathrm{W}$ & 1988 & 2000 & Stream & 92 \\
\hline 20. Bencrom River & UK (N.Ireland) & $54^{\circ} 10^{\prime} \mathrm{N}$ & $5^{\circ} 56^{\prime} \mathrm{W}$ & 1988 & 2000 & Stream & 3 \\
\hline 21. Blue Lough & UK (N.Ireland) & $54^{\circ} 11^{\prime} \mathrm{N}$ & $5^{\circ} 54^{\prime} \mathrm{W}$ & 1990 & 2000 & Lake & -32 \\
\hline 22. Coneyglen Burn & UK (N.Ireland) & $54^{\circ} 40^{\prime} \mathrm{N}$ & $7^{\circ} 03^{\prime} \mathrm{W}$ & 1990 & 2000 & Stream & 168 \\
\hline 23. Kaarvatn & Norway & $62^{\circ} 47^{\prime} \mathrm{N}$ & $8^{\circ} 53^{\prime} \mathrm{E}$ & 1980 & 1999 & Stream & 26 \\
\hline 24. Langtjern & Norway & $60^{\circ} 22^{\prime} \mathrm{N}$ & $9^{\circ} 39^{\prime} \mathrm{E}$ & 1980 & 1999 & Stream & 22 \\
\hline 25. Storgama & Norway & $59^{\circ} 01^{\prime} \mathrm{N}$ & $8^{\circ} 32^{\prime} \mathrm{E}$ & 1980 & 1999 & Stream & -23 \\
\hline 26. Birkenes & Norway & $58^{\circ} 23^{\prime} \mathrm{N}$ & $8^{\circ} 15^{\prime} \mathrm{E}$ & 1980 & 1999 & Stream & -37 \\
\hline 27. Ringsmöbäcken & Sweden & $58^{\circ} 59^{\prime} \mathrm{N}$ & $11^{\circ} 45^{\prime} \mathrm{E}$ & 1985 & 1999 & Stream & 8 \\
\hline 28. Lommabäcken & Sweden & $58^{\circ} 42^{\prime} \mathrm{N}$ & $14^{\circ} 38^{\prime} \mathrm{E}$ & 1985 & 1999 & Stream & -6 \\
\hline 29. Bratangsbäcken & Sweden & $58^{\circ} 42 \varnothing \mathrm{N}$ & $14^{\circ} 38^{\prime} \mathrm{E}$ & 1985 & 1999 & Stream & 39 \\
\hline 30. Gårdsjön F1 & Sweden & $58^{\circ} 03^{\prime} \mathrm{N}$ & $12^{\circ} 01^{\prime} \mathrm{E}$ & 1980 & 1999 & Stream & -111 \\
\hline 31. Pipbäcken & Sweden & $57^{\circ} 03^{\prime} \mathrm{N}$ & $12^{\circ} 47^{\prime} \mathrm{E}$ & 1985 & 1999 & Stream & 1 \\
\hline 32. Valkeakotinen & Finland & $61^{\circ} 14^{\prime} \mathrm{N}$ & $25^{\circ} 04^{\prime} \mathrm{E}$ & 1988 & 1999 & Stream & 71 \\
\hline 33. Hietajärvi & Finland & $63^{\circ} 10^{\prime} \mathrm{N}$ & $30^{\circ} 43^{\prime} \mathrm{E}$ & 1988 & 1999 & Stream & 105 \\
\hline 34. Lange Bramke & Germany & $51^{\circ} 52^{\prime} \mathrm{N}$ & $10^{\circ} 26^{\prime} \mathrm{E}$ & 1980 & 1999 & Stream & -67 \\
\hline 35. Dicke Bramke & Germany & $51^{\circ} 52^{\prime} \mathrm{N}$ & $10^{\circ} 26^{\prime} \mathrm{E}$ & 1980 & 1999 & Stream & 64 \\
\hline 36. Metzenbach & Germany & $49^{\circ} 54^{\prime} \mathrm{N}$ & $9^{\circ} 26^{\prime} \mathrm{E}$ & 1987 & 1999 & Stream & 97 \\
\hline 37. Lehstenbach & Germany & $50^{\circ} 09^{\prime} \mathrm{N}$ & $11^{\circ} 52^{\prime} \mathrm{E}$ & 1987 & 1999 & Stream & -36 \\
\hline 38. Schluchsee & Germany & $47^{\circ} 49^{\prime} \mathrm{N}$ & $8^{\circ} 06^{\prime} \mathrm{E}$ & 1987 & 1996 & Stream & 33 \\
\hline 39. Villingen & Germany & $48^{\circ} 03^{\prime} \mathrm{N}$ & $8^{\circ} 22^{\prime} \mathrm{E}$ & 1987 & 1996 & Stream & 15 \\
\hline 40. Markungsgraben & Germany & $48^{\circ} 57^{\prime} \mathrm{N}$ & $13^{\circ} 25^{\prime} \mathrm{E}$ & 1987 & 1999 & Stream & 10 \\
\hline 41.Ėerné & Czech R. & $49^{\circ} 11^{\prime} \mathrm{N}$ & $13^{\circ} 11^{\prime} \mathrm{E}$ & 1984 & 1999 & Lake & -16 \\
\hline 42.Èertovo & Czech R. & $49^{\circ} 10^{\prime} \mathrm{N}$ & $13^{\circ} 12^{\prime} \mathrm{E}$ & 1984 & 1999 & Lake & -38 \\
\hline 43. Prašilské & Czech R. & $49^{\circ} 05^{\prime} \mathrm{N}$ & $13^{\circ} 23^{\prime} \mathrm{E}$ & 1984 & 1999 & Lake & -17 \\
\hline 44. Zdarské & Czech R. & $48^{\circ} 56^{\prime} \mathrm{N}$ & $13^{\circ} 39^{\prime} \mathrm{E}$ & 1984 & 1999 & Lake & 73 \\
\hline 45. Laka & Czech R. & $49^{\circ} 07^{\prime} \mathrm{N}$ & $13^{\circ} 20^{\prime} \mathrm{E}$ & 1984 & 1999 & Lake & 16 \\
\hline 46. Plešné & Czech R. & $48^{\circ} 47^{\prime} \mathrm{N}$ & $13^{\circ} 52^{\prime} \mathrm{E}$ & 1984 & 1999 & Lake & -10 \\
\hline 47. Slavkovské & Slovakia & $49^{\circ} 09^{\prime} \mathrm{N}$ & $20^{\circ} 11^{\prime} \mathrm{E}$ & 1984 & 1999 & Lake & -9 \\
\hline 48. Batizovské & Slovakia & $49^{\circ} 09^{\prime} \mathrm{N}$ & $20^{\circ} 07^{\prime} \mathrm{E}$ & 1982 & 1999 & Lake & 22 \\
\hline 49. Vyšné Wahlenbergovo & Slovakia & $49^{\circ} 10^{\prime} \mathrm{N}$ & $20^{\circ} 01^{\prime} \mathrm{E}$ & 1980 & 1999 & Lake & 9 \\
\hline 50. Malé Hincovo & Slovakia & $49^{\circ} 10^{\prime} \mathrm{N}$ & $20^{\circ} 03^{\prime} \mathrm{E}$ & 1984 & 1999 & Lake & 266 \\
\hline 51. Jamské & Slovakia & $49^{\circ} 08^{\prime} \mathrm{N}$ & $20^{\circ} 00^{\prime} \mathrm{E}$ & 1984 & 1999 & Lake & -17 \\
\hline 52. Lago Paoine Superiore & Italy & $46^{\circ} 11^{\prime} \mathrm{N}$ & $8^{\circ} 11^{\prime} \mathrm{E}$ & 1980 & 1999 & Lake & 4 \\
\hline 53. Lago Paoine Inferiore & Italy & $46^{\circ} 10^{\prime} \mathrm{N}$ & $8^{\circ} 11^{\prime} \mathrm{E}$ & 1980 & 1999 & Lake & 29 \\
\hline 54. Pellesino & Italy & $45^{\circ} 47^{\prime} \mathrm{N}$ & $8^{\circ} 04^{\prime} \mathrm{E}$ & 1986 & 1999 & Stream & 173 \\
\hline 55. Pellino & Italy & $45^{\circ} 48^{\prime} \mathrm{N}$ & $8^{\circ} 04^{\prime} \mathrm{E}$ & 1984 & 1999 & Stream & 199 \\
\hline 56. Cannobino & Italy & $46^{\circ} 04^{\prime} \mathrm{N}$ & $8^{\circ} 42^{\prime} \mathrm{E}$ & 1980 & 1999 & Stream & 216 \\
\hline
\end{tabular}


